\title{
Influence of Superheating Melt Treatment on Microstructure of Gd-Modified Al-15wt.\% Mg2Si In-Situ Composite
}

\author{
I. Prima Nanda1 ${ }^{1}$ H. Ghandvar ${ }^{2}$, M.H. Idris ${ }^{2}$ and A. Arafat ${ }^{3}$ \\ ${ }^{1}$ Department of Mechanical Engineering, Faculty of Engineering, Universitas Andalas, Padang, 25163 Sumatera Barat, Indonesia \\ 2Department of Materials, Manufacturing and Industrial Engineering, School of Mechanical Engineering, Faculty of Engineering, \\ Universiti Teknologi Malaysia (UTM), 81310 Johor Bahru, Malaysia \\ Phone: +601169375515; Fax: +607-5566159 \\ 3Department of Mechanical Engineering, Faculty of Engineering, Universitas Negeri Padang, 25131 Sumatera Barat, Indonesia
}

\begin{abstract}
The influence of melt superheating treatment with different superheating temperatures $\left(750,800,850\right.$, and $\left.900^{\circ} \mathrm{C}\right)$ on the microstructure of $\mathrm{Al}-15 \mathrm{wt} . \% \mathrm{Mg}_{2} \mathrm{Si}$ composites before and after addition of $\mathrm{Gd}(1.0 \mathrm{wt} . \%)$ were studied. Microstructure characterisation was carried out via optical microscopy (OM) and x-ray diffraction (XRD). The results showed that in the unmodified composite, when the temperature of superheating raised from $750^{\circ} \mathrm{C}$ to $900^{\circ} \mathrm{C}$, the primary $\mathrm{Mg}_{2} \mathrm{Si}$ experienced a decrease of the average grain size from 40 to about $32 \mu \mathrm{m}$, while, in the Gd-modified composite, the particle size was refined considerably from 27 to $13 \mu \mathrm{m}$ by increasing the temperature from $750^{\circ} \mathrm{C}$ to $850^{\circ} \mathrm{C}$. Furthermore, with a further increase in temperature to $900^{\circ} \mathrm{C}$, the particle size slightly increased to about $15 \mu \mathrm{m}$ which might be due to the burning loss of $\mathrm{Gd}$ in the melt. Nevertheless, for both unmodified and Gd-modified composites, the superheating temperature exhibited minor influence on the $\mathrm{Mg}_{2} \mathrm{Si}$ crystals morphologies. It is believed that compiling of $\mathrm{Gd}$ addition and superheating melt treatment is efficient to improve the composite properties that could encounter the application requirements.
\end{abstract}

ARTICLE HISTORY

Revised: $20^{\text {th }}$ June 2020

Accepted: $29^{\text {th }}$ June 2020

\section{KEYWORDS}

Aluminum matrix composite (AMC); $\mathrm{Mg}_{2} \mathrm{Si}$, Superheating temperature; Modification

\section{INTRODUCTION}

Recently, $\mathrm{Al}-\mathrm{Mg}_{2} \mathrm{Si}$ in-situ composite received considerable interest in the automotive industry, due to its desirable properties which is due to the existence of the $\mathrm{Mg}_{2} \mathrm{Si}$ phase [1-5]. However, during fabrication of the composite under low solidification rate (e.g. gravity casting), the formation of coarse and irregular morphology of primary and eutectic $\mathrm{Mg}_{2} \mathrm{Si}$ phases in the Al-Mg-Si melt worsens the mechanical properties of $\mathrm{Al}-\mathrm{Mg}_{2} \mathrm{Si}$ composite which restricts its development and applications[1,2]. Therefore, it is essential to alter the structure of primary and eutectic $\mathrm{Mg}_{2} \mathrm{Si}$ phase with the purpose of the mechanical properties of the subjected composite [1,2].

Besides modification, it has been proposed from different perspectives that for the purpose of refinement, superheating melt treatment is a modest and efficient method [6-13]. Nordin et al. [14] reported that at a superheated temperature of $950{ }^{\circ} \mathrm{C}$ and holding time of 15 minutes, the primary $\mathrm{Mg}_{2} \mathrm{Si}$ with skeleton structure experienced size decrement of its fine polygonal structure. Furthermore, Saffari et al. [15] claimed that by increasing the superheating melt temperature, the primary $\mathrm{Mg}_{2} \mathrm{Si}$ particles size reduced compared to the $\mathrm{Mg}_{2} \mathrm{Si}$ particles in samples produced by gravity casting and vibrating cooling slope (VCS). Nevertheless, the exact refinement mechanism of superheating treatment is still blurry; in addition, there are some inconsistencies in its description. According to the first researcher's findings, the particles are not able to act as nuclei at normal pouring temperature as they are not small enough, while they may dissolve at high temperatures and then the fine particles are reformed or precipitated which are appropriate for nucleation of small particles $[9,10]$. Another explanation attributes to particle refinement is the heredity phenomenon in the materials in which during the process of melting, clusters and solid particles that survived, may have influences on the re-solidified structures [7,8]. For example, Chen et al. [8] claimed that the modification of eutectic $\mathrm{Si}$ in $\mathrm{Al}-7 \mathrm{Si}-0.55 \mathrm{Mg}$ melt by superheating treatment is by decreasing the $\mathrm{Si}-\mathrm{Si}$ clusters heredity and altering its growth manner.

Furthermore, $\mathrm{Li}$ et al. [13] reported that the heredity of Al-16Si alloy decreased at high superheating temperature $\left(1050^{\circ} \mathrm{C}\right)$. Increasing in undercooling by superheating is another explanation responsible for particle refinement. In fact, by increasing the superheating temperature, the thermal diffusion leads to a more uniform distribution of alloying elements, which obviously influence the undercooling and consequent solidification process[12,14]. For instance, Yin et al. [16] found that at elevated superheating temperature (over $1873 \mathrm{~K}$ ); the M963 alloy was refined due to high undercooling in the melt.

In contrast to the explanations mentioned above, it is believed that at high superheating temperature establishment of new heterogeneous nucleus results in the refinement of the particles [9,17]. In another study [9], it was proposed that in Mg-Al-Mn alloys, superheating melt treatment can generate $\varepsilon-\mathrm{Al}-\mathrm{Mn}$ phase at high temperature, which moderately form into metastable $\tau$-Al-Mn phase, and can turn into an efficient non-homogeneous nucleation substrate. 
Although there are several studies about the role of superheating treatment on the $\mathrm{Mg}_{2} \mathrm{Si}$ particles refinement of in $\mathrm{Al}$ or $\mathrm{Mg}$ composite reinforced with $\mathrm{Mg}_{2} \mathrm{Si}$, limitations exist on the influence of different temperatures of superheating on refinement/modification of $\mathrm{Mg}_{2} \mathrm{Si}$ phases in RE-modified $\mathrm{Al}-\mathrm{Mg}_{2} \mathrm{Si}$ composites. Therefore, in the current work, superheating process on $\mathrm{Al}-\mathrm{Mg}_{2} \mathrm{Si}$ composite melts without and with Gd addition as well as their effects on the microstructure features are examined experimentally.

\section{MATERIALS AND METHOD}

To produce $\mathrm{Al}-15 \% \mathrm{Mg}_{2} \mathrm{Si}$ composite ingot, pure industrial grade $\mathrm{Al}, \mathrm{Si}$ and $\mathrm{Mg}$ were used. In which, with the aid of a resistance furnace, $\mathrm{Al}$ and $\mathrm{Si}$ melts were achieved at $800{ }^{\circ} \mathrm{C}$, and once temperature decreased to $750{ }^{\circ} \mathrm{C}$, the melt was inserted with pure $\mathrm{Mg}$. After homogenisation and removing of the dross, the melt was poured into a metal mould. The compositions of the elements exist in Al-15wt.\% $\mathrm{Mg}_{2} \mathrm{Si}$ composite is demonstrated in Table 1. After cutting off the composite ingot into small pieces, an electric resistance furnace was used to melt $100 \mathrm{~g}$ of the $\mathrm{Al}-15 \mathrm{wt} . \% \mathrm{Mg} 2 \mathrm{Si}$ ingot. After holding the melt for $5 \mathrm{~min}$ in the designed temperature $\left(750{ }^{\circ} \mathrm{C}\right)$, Al-10Gd master alloy was added to the melts to achieve the designed Al-15wt. \% $\mathrm{Mg}_{2} \mathrm{Si}-1.0$ wt. \% Gd. After manually stirring the melt with a stainless steel impeller, it was held for $15 \mathrm{~min}$ at the pre-set temperature of $750{ }^{\circ} \mathrm{C}$ and then poured into a preheated steel mould $\left(100{ }^{\circ} \mathrm{C}\right)$ to fabricate cylindrical samples with $30 \mathrm{~mm}$ diameter. The same procedure was repeated for temperatures of 800,850 and $900{ }^{\circ} \mathrm{C}$. The standard metallographic procedure of the samples was initiated with the etching of the samples at room temperature using $0.5 \% \mathrm{HF}$ (volume fraction) for about 5s. Optical microscopy (OM) (Nikon-MICROPHOT-FXL) and x-ray diffraction (XRD) (Siemens D500 x-ray diffractometer with a $\mathrm{Cu} \mathrm{K \alpha}$ line) were used to examine the microstructure characteristics of the specimens. Furthermore, to estimate the particle size, the intercept method was conducted on the microstructure with low magnification, and the calculation was carried out on at least 70 particles.

Table 1. The composition of the elements exists in $\mathrm{Al}-15 \% \mathrm{Mg}_{2} \mathrm{Si}$ (wt. \%) ingot.

\begin{tabular}{lc}
\hline Element & Weight (\%) \\
\hline $\mathrm{Al}$ & 84.60 \\
$\mathrm{Mg}$ & 8.50 \\
$\mathrm{Si}$ & 6.70 \\
$\mathrm{Fe}$ & 0.12 \\
$\mathrm{~V}$ & 0.02 \\
$\mathrm{Cr}$ & 0.01 \\
$\mathrm{Ni}$ & 0.01 \\
$\mathrm{Mn}$ & 0.01 \\
\hline
\end{tabular}

\section{RESULTS AND DISCUSSION}

\section{Analysis of X-ray Diffraction (XRD)}

Figure 1 illustrates the XRD pattern of unmodified and 1.0wt. \% Gd modified Al-15wt. \% $\mathrm{Mg}_{2} \mathrm{Si}_{\text {composites }}$ processed at $750{ }^{\circ} \mathrm{C}$ and $900{ }^{\circ} \mathrm{C}$. As observed, all composites consisted of $\mathrm{Al}$ and $\mathrm{Mg}_{2} \mathrm{Si}$ phases as expected, in addition to $\mathrm{Al}_{2} \mathrm{Si}_{2} \mathrm{Gd}$ and $\mathrm{AlSiGd}$ owning to the Gd intermetallic compounds (IMCs) formation in the Gd-treated samples. Therefore, it indicates that the increase in temperature from $750-900^{\circ} \mathrm{C}$ had no effect on the phase compositions of $\mathrm{Al}-$ 15 wt. $\% \mathrm{Mg}_{2} \mathrm{Si}$ composites.

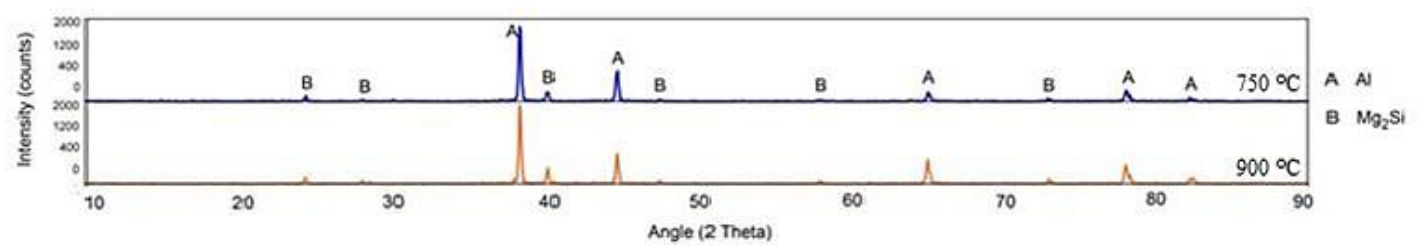

(a)

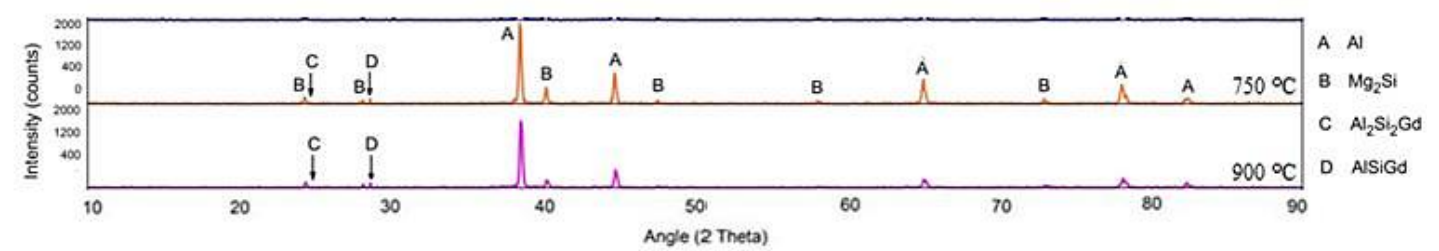

(b)

Figure 1. XRD patterns of Al-15wt. \% $\mathrm{Mg}_{2} \mathrm{Si}$ composites in (a) untreated and (b) Gd-treated conditions at $750{ }^{\circ} \mathrm{C}$ and $900{ }^{\circ} \mathrm{C}$ temperatures 


\section{Analysis of Microstructure}

Figure 2 and 3 depict the effect of superheating temperatures on the microstructure of the unmodified and Gd-modified Al-15wt. $\% \mathrm{Mg}_{2} \mathrm{Si}$ composites, respectively. As seen in Figure 2(a) to 2(d), with increase of temperature, the grain size of the primary $\mathrm{Mg}_{2} \mathrm{Si}$ particles decreased in the unmodified composite. Furthermore, the significant changes in the size of the primary $\mathrm{Mg}_{2} \mathrm{Si}$ particles are as depicted in Figure 3(a) to 3(d).
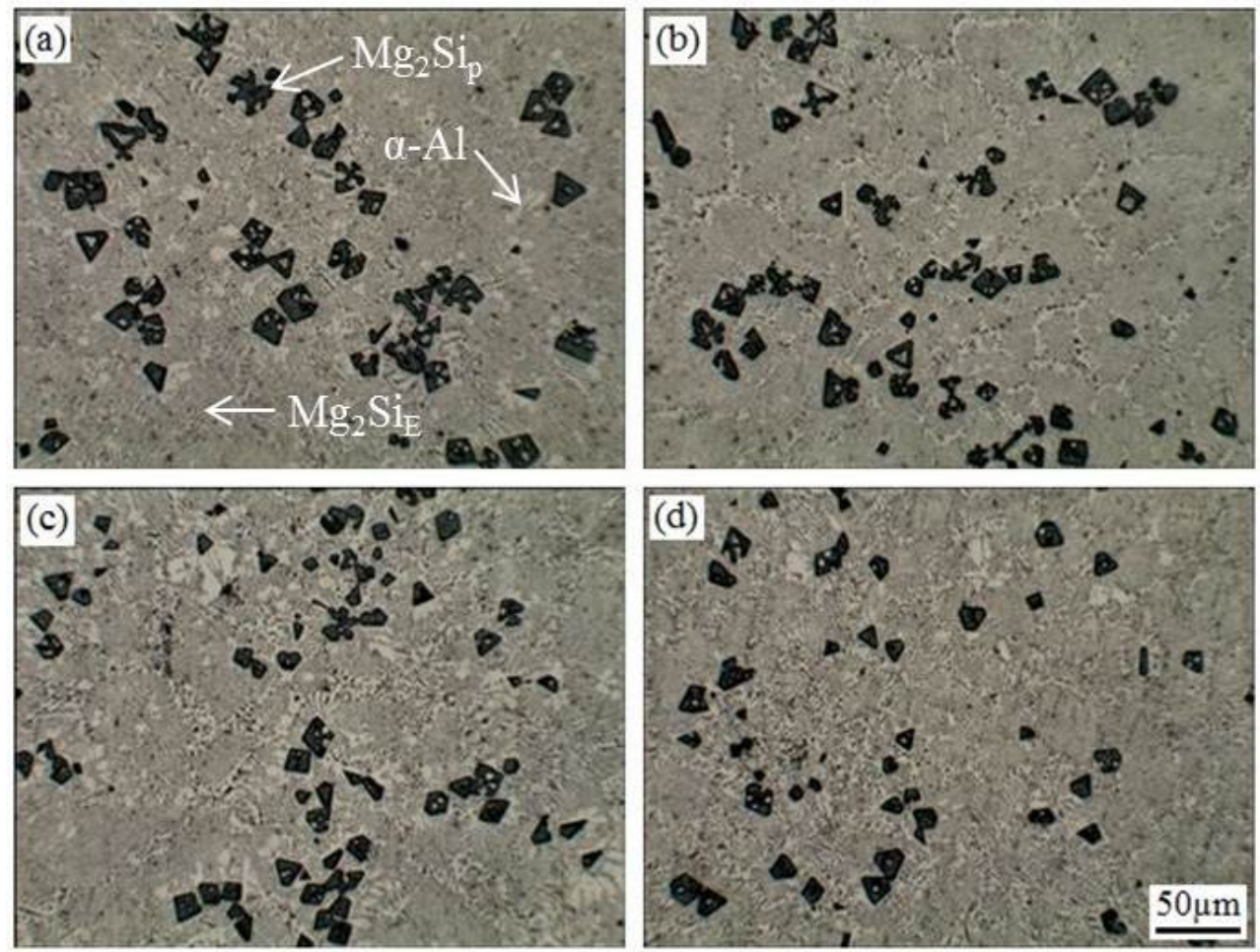

Figure 2. OM micrographs of untreated $\mathrm{Al}-15 \mathrm{wt} . \% \mathrm{Mg}_{2} \mathrm{Si}$ composites at different temperatures of superheating: (a) $750{ }^{\circ} \mathrm{C}$; (b) $800{ }^{\circ} \mathrm{C}$; (c) $850{ }^{\circ} \mathrm{C}$; (d) $900{ }^{\circ} \mathrm{C}$
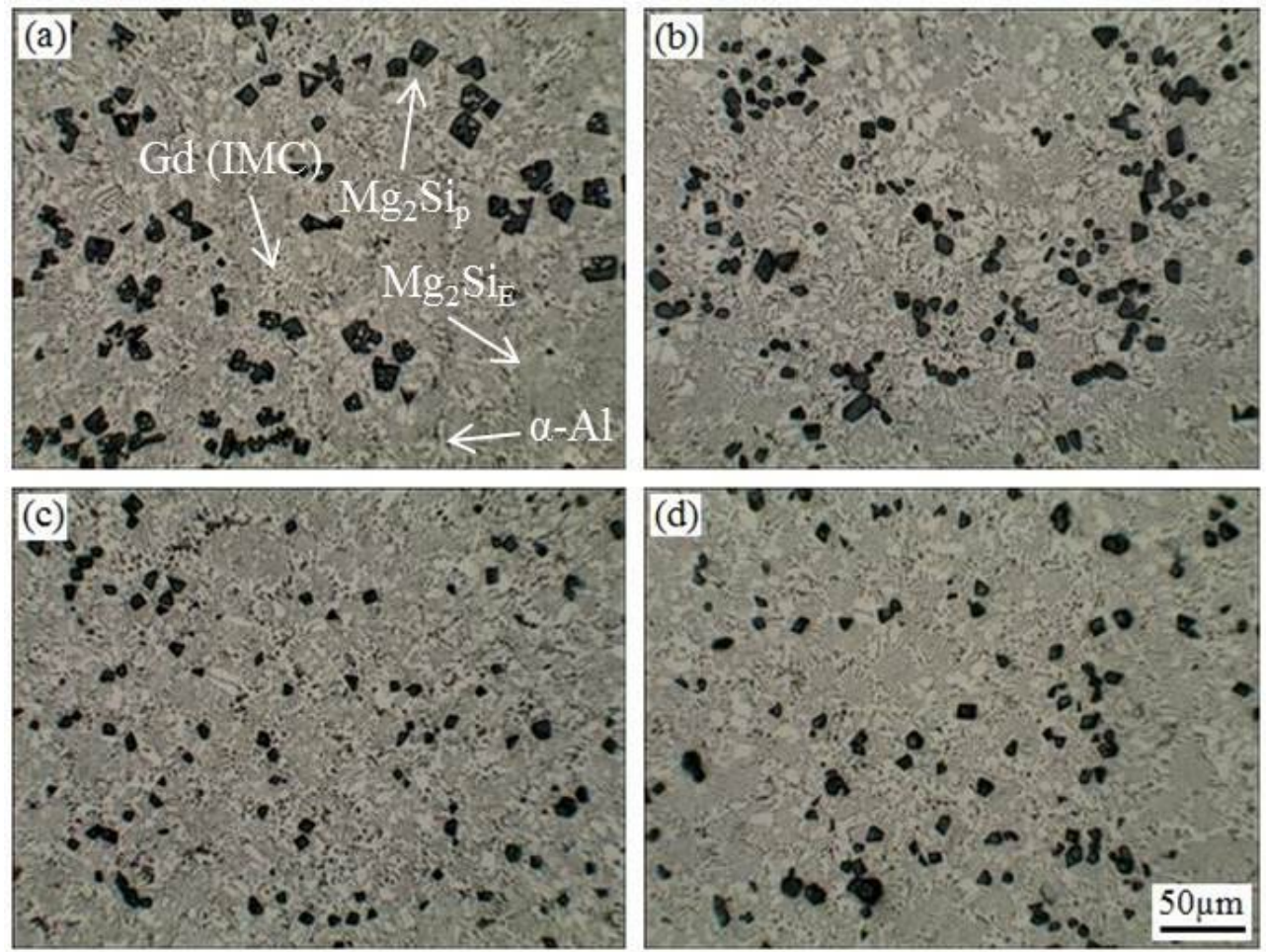

Figure 3. $\mathrm{OM}$ micrographs of Gd-treated $\mathrm{Al}-15 \mathrm{wt} . \% \mathrm{Mg}_{2} \mathrm{Si}$ composites at different temperatures of superheating: (a) $750{ }^{\circ} \mathrm{C}$, (b) $800{ }^{\circ} \mathrm{C}$, (c) $850{ }^{\circ} \mathrm{C}$ and (d) $900{ }^{\circ} \mathrm{C}$

Figure 4(a) and 4(b) illustrate the changes in the size of primary $\mathrm{Mg}_{2} \mathrm{Si}$ particle in both unmodified and Gd-modified composites as a function of melt superheating temperature, respectively. When the temperature increased from $750^{\circ} \mathrm{C}$ to 
$900^{\circ} \mathrm{C}$, the coarse dendritic primary $\mathrm{Mg}_{2} \mathrm{Si}$ particles was refined considerably in the unmodified composite, from larger than $40 \mu \mathrm{m}$ to $32 \mu \mathrm{m}$ or less (as in Figure 4(a)). Simultaneously, the density of $\mathrm{Mg}_{2} \mathrm{Si}$ particles increased as a result of size reduction and showed that in the matrix of $\mathrm{Al}$, the particles are distributed uniformly as shown in Figure 2(a) to 2(d). As seen in Figure 4(b), a considerable reduction can be detected in $\mathrm{Mg}_{2} \mathrm{Si}$ particles size from about $27 \mu \mathrm{m}$ to $13 \mu \mathrm{m}$ in the modified composite with an increase in temperature from $750{ }^{\circ} \mathrm{C}$ to $850{ }^{\circ} \mathrm{C}$. With further increase in temperature to $900{ }^{\circ} \mathrm{C}$, the modified $\mathrm{Mg}_{2} \mathrm{Si}$ particles showed a reverse trend, and the particles became coarser with the increased size of about $15 \mu \mathrm{m}$; refer to Figure 4 (b). Thus, the temperature of $850{ }^{\circ} \mathrm{C}$ is considered as the proper superheating temperature for the goal of primary $\mathrm{Mg}_{2} \mathrm{Si}$ particles refinement in $\mathrm{Al}-15 \mathrm{wt} . \% \mathrm{Mg}_{2} \mathrm{Si}$ composites.

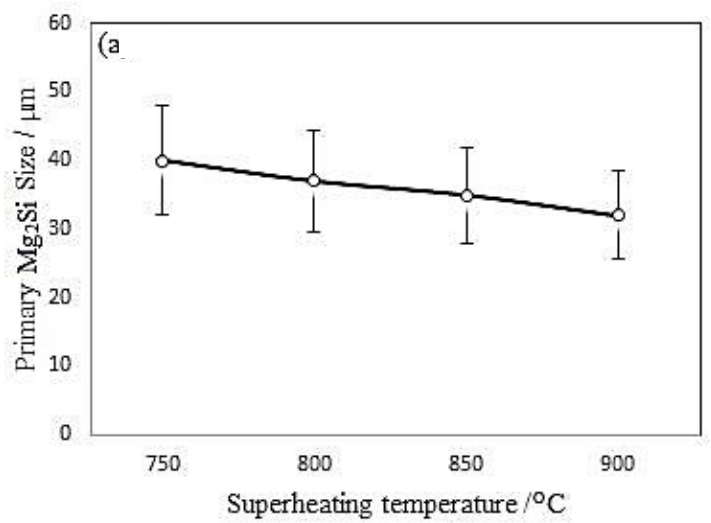

(a)

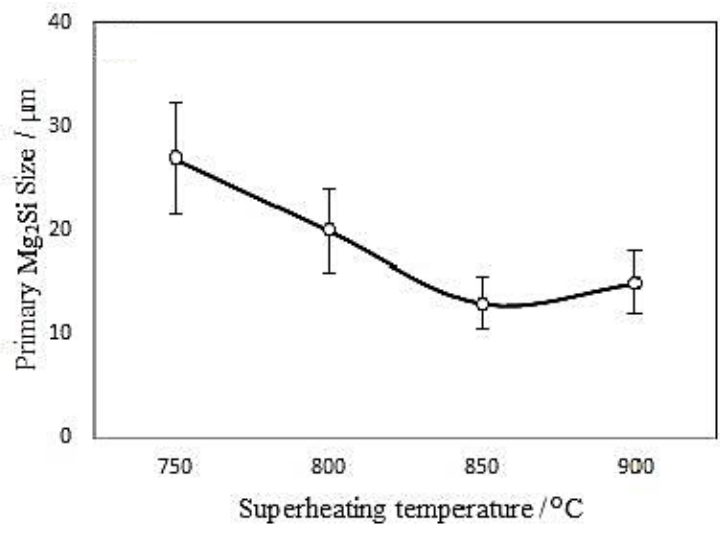

(b)

Figure 4. Influence of temperature of superheating on the size of primary $\mathrm{Mg}_{2} \mathrm{Si}$ particles in $\mathrm{Al}-15 \mathrm{wt} . \% \mathrm{Mg}_{2} \mathrm{Si}$ composites in (a) untreated; (b) Gd-treated.

From the comparison between Figure 2 and Figure 3, it can be taken into account that the primary $\mathrm{Mg}_{2} \mathrm{Si}$ crystal altered from a coarse dendritic structure to a fine truncated octahedral shape. Moreover, the eutectic $\mathrm{Mg}_{2} \mathrm{Si}$ crystal transformed from Chinese script shape to fibre-like structure. The results show that the Gd addition can efficiently modify the $\mathrm{Mg}_{2} \mathrm{Si}$ particles, in which the corresponding modification mechanism is discussed later. The magnified images of $\mathrm{Mg}_{2} \mathrm{Si}$ particles in unmodified and Gd-modified Al-15wt. \% $\mathrm{Mg}_{2} \mathrm{Si}$ composites at different superheating temperatures of $750^{\circ} \mathrm{C}$ and $900^{\circ} \mathrm{C}$ are illustrated in Figure 5 and 6, respectively.
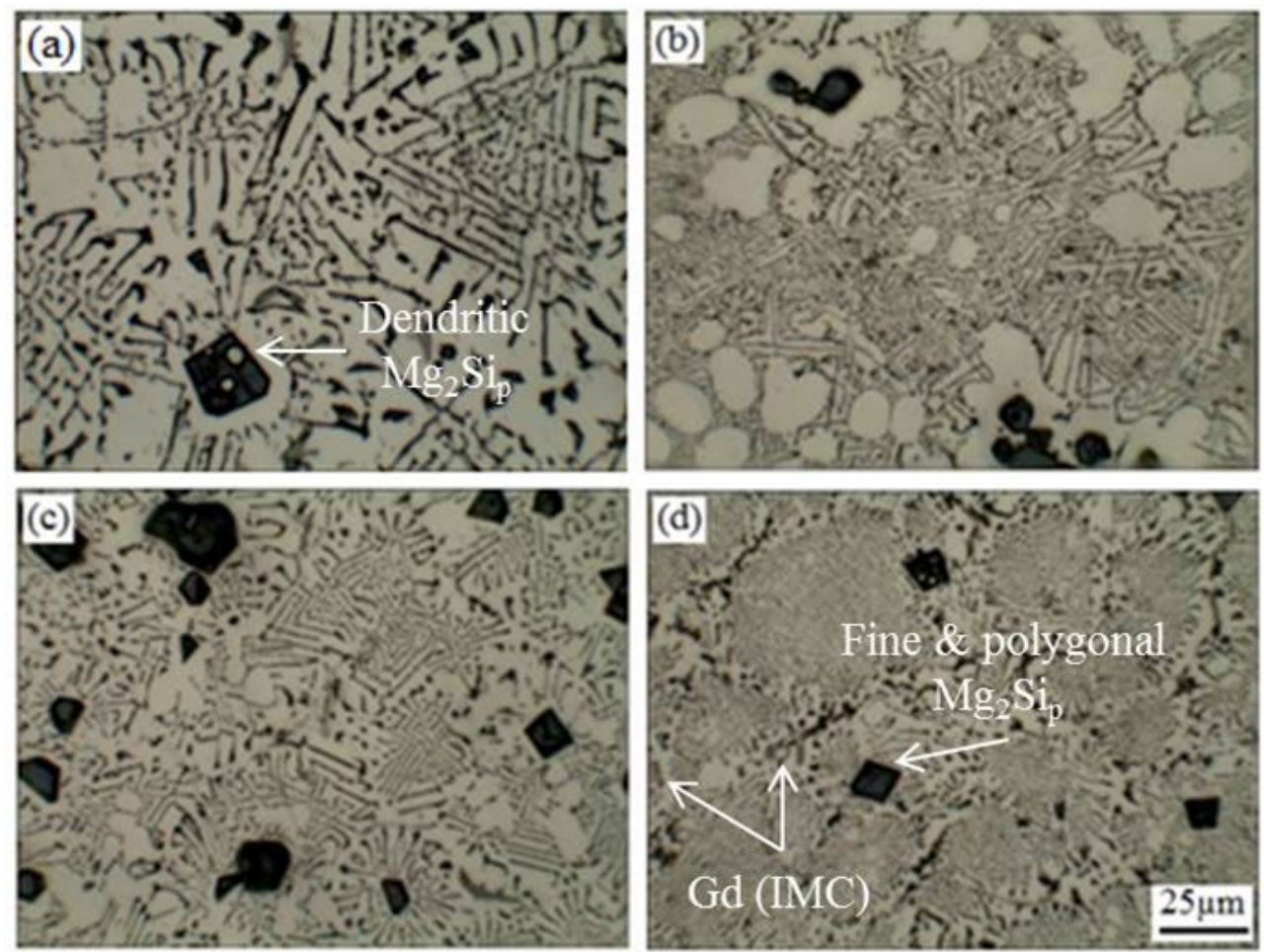

Figure 5. Magnified structures of primary $\mathrm{Mg}_{2} \mathrm{Si}$ in $\mathrm{Al}-15 \mathrm{wt} . \% \mathrm{Mg}_{2} \mathrm{Si}$ composites in untreated and Gd-treated conditions in at various temperatures of superheating: (a) $750{ }^{\circ} \mathrm{C}$ (untreated); (b) $900{ }^{\circ} \mathrm{C}$ (untreated); (c) $750{ }^{\circ} \mathrm{C}$ (treated); (d) $900{ }^{\circ} \mathrm{C}$ (treated) 

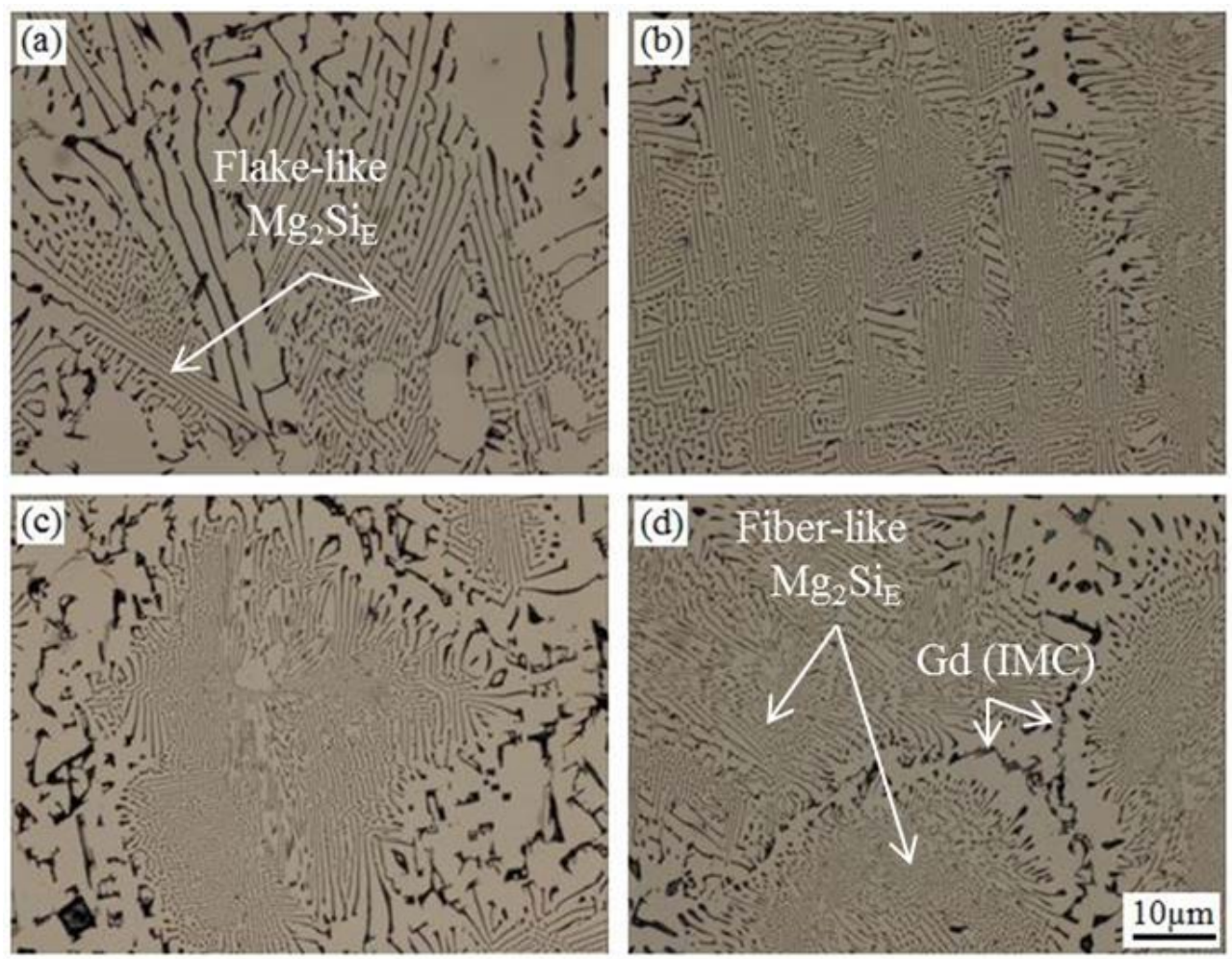

Figure 6. Magnified structures of eutectic $\mathrm{Mg}_{2} \mathrm{Si}$ in $\mathrm{Al}-15 \mathrm{wt} . \% \mathrm{Mg}_{2} \mathrm{Si}$ composites in untreated and Gd-treated conditions in at various temperatures of superheating: (a) $750{ }^{\circ} \mathrm{C}$ (untreated); (b) $900{ }^{\circ} \mathrm{C}$ (untreated); (c) $750{ }^{\circ} \mathrm{C}$ (treated); (d) $900{ }^{\circ} \mathrm{C}$ (treated)

\section{Mechanism of Particle Refinement/Modification}

The reduction of heredity is one of the explanations for particle refinement. In $\mathrm{Al}-\mathrm{Si}-\mathrm{Mg}-\mathrm{Cu}$, morphology transformations of the primary $\mathrm{Mg}_{2} \mathrm{Si}$ particles after superheating melt treatment due to alteration of the initial structure and melt heredity, as proposed by QIN et al. [12]. Furthermore, the decrease of heredity has a significant influence in $\mathrm{Mg}_{2} \mathrm{Si}$ particles refinement in $\mathrm{Mg}-1.5 \mathrm{Si}-1 \mathrm{Zn}$ alloy during superheating melt treatment, as proposed in another study [2]. In the present study, it is proposed that in the unmodified $\mathrm{Al}-15 \mathrm{wt} . \% \mathrm{Mg}_{2} \mathrm{Si}$ composite, refinement of $\mathrm{Mg}_{2} \mathrm{Si}$ phases (both primary and eutectic) after superheating treatment is because of the reduction in heredity. It is believed that in low superheating temperature $\left(\right.$ e.g. $\left.750^{\circ} \mathrm{C}\right)$, there are a number of solid spots and somewhat atom clusters with large movements which have similar features to the ingot in the melt because of heredity. The nucleation occurs due to the existence of solid spots and large clusters; thus, during subsequent solidification procedure, the particles grow coarser easily. When the superheating temperature is increased, the atom clusters with large moving feature and solid particles dissolve gradually and form into fine clusters which are suitable for small particles nucleation. For Gd-modified Al-15 wt. $\% \mathrm{Mg}_{2} \mathrm{Si}$ composite, the mechanism of refinement of $\mathrm{Mg}_{2} \mathrm{Si}$ particles is due to the probable descriptions as follows:

i. For the refinement of $\mathrm{Mg}_{2} \mathrm{Si}$ particles in Gd-modified composite, the decrease of heredity plays a significant role.

ii. The existence of $\mathrm{Gd}$ addition in melt leads to refinement and modification of the $\mathrm{Mg}_{2} \mathrm{Si}$ particles due to the presence of $\mathrm{Al}_{3} \mathrm{Gd}$ phase as non-homogeneous nucleation substrates for primary $\mathrm{Mg}_{2} \mathrm{Si}$ particles and poisoning effect of Gd element, as well as restricted growth mechanism as a result of presence of Gd rich intermetallics (AlSiGd, $\mathrm{Al}_{2} \mathrm{Si}_{2} \mathrm{Gd}$ ) in the composite structure (of Figure 1), which promotes particle size reduction [18]. Nonetheless, the burning loss of the $\mathrm{Gd}$ in the melt occurred at elevated superheating temperature (i.e. $900{ }^{\circ} \mathrm{C}$ ), which led to a minor increase in the particle size; refer to Figure 3(d) and 4(b).

\section{Hardness Properties}

The influence of the superheating process on the hardness property of $\mathrm{Al}-15 \% \mathrm{Mg}_{2} \mathrm{Si}$ composites with and without $\mathrm{Gd}$ addition is illustrated in Figure 7. It can be observed that the hardness of both unmodified and Gd-modified composites increased when the temperature of superheating is increased. However, in the Gd-modified composites, further increase of the temperature to $900{ }^{\circ} \mathrm{C}$ resulted in the decrease of the hardness value, which is due to the reduction of the modification effect of $\mathrm{Gd}$ on the $\mathrm{Mg}_{2} \mathrm{Si}$ particles, owing to burning of the $\mathrm{Gd}$ element at high temperature $\left(900{ }^{\circ} \mathrm{C}\right)$. In fact, the formation and $\mathrm{Mg}_{2} \mathrm{Si}$ particles distribution in the matrix of the composites affect the hardness of the fabricated materials [19]. The hardness of the composites was enhanced when the particles are distributed homogeneously in the matrix, as harder ceramic particles can resist the stress [20,21]. As depicted in Figure 7, higher superheat temperature contributed to better particles distribution, which affected the hardness of the composites. When the superheat temperature increased from $750{ }^{\circ} \mathrm{C}$ to $900^{\circ} \mathrm{C}$, the hardness values of the unmodified composites increased from $54.98 \mathrm{HV}$ to $65.30 \mathrm{HV}$. 
In addition, the hardness value of Gd-modified composites increased from $67.36 \mathrm{HV}$ to $73.17 \mathrm{HV}$ with increasing the temperature of superheating from $750{ }^{\circ} \mathrm{C}$ to $850{ }^{\circ} \mathrm{C}$.

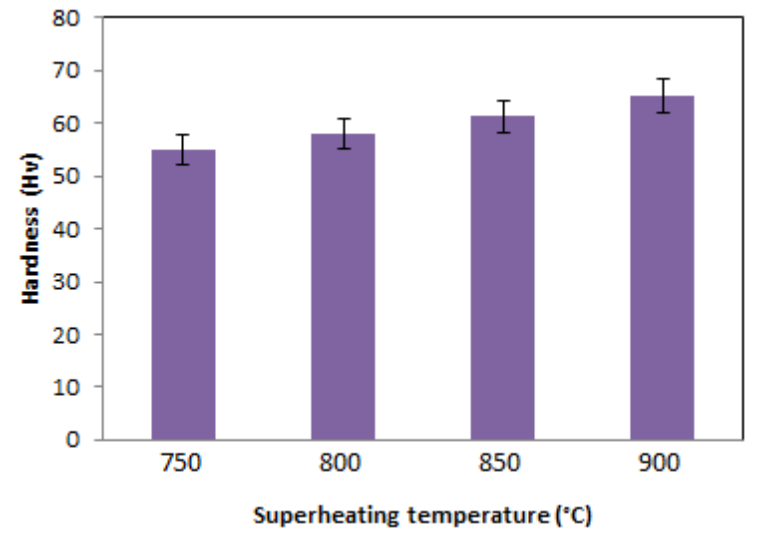

(a)

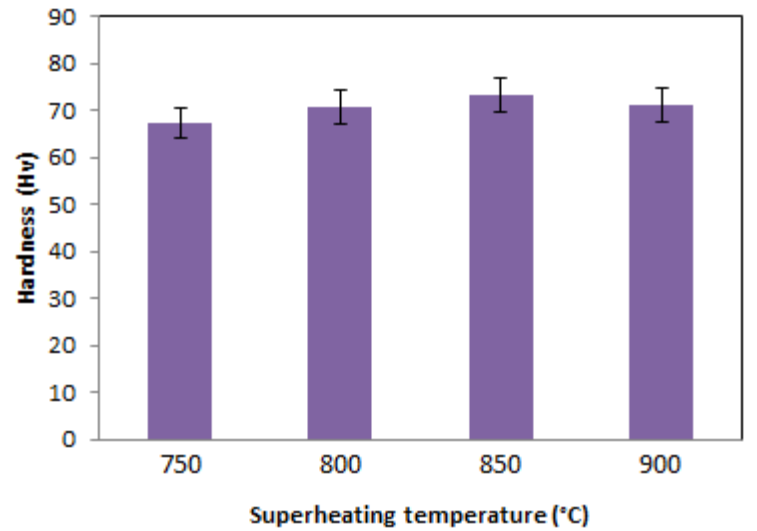

(b)

Figure 7. Hardness values as a result of different temperatures of superheating in (a) untreated and (b) Gd-treated Al$15 \% \mathrm{Mg}_{2} \mathrm{Si}$ composites.

\section{CONCLUSION}

The influence of the superheating melt treatment on microstructure and hardness property of $\mathrm{Al}-15 \% \mathrm{Mg}_{2} \mathrm{Si}$ in-situ composites in unmodified and $1.0 \mathrm{wt} . \%$ Gd-modified conditions was investigated. The concluding observations are as follow:

i. To obtain a refined $\mathrm{Mg}_{2} \mathrm{Si}$ particles in $\mathrm{Al}-\mathrm{Mg}_{2} \mathrm{Si}$ composites, superheating melt treatment can be a good option, in which in the unmodified Al-15wt. \% $\mathrm{Mg}_{2} \mathrm{Si}$ composite, the coarse $\mathrm{Mg}_{2} \mathrm{Si}$ particles was refined progressively by increasing the temperature of superheating from $750{ }^{\circ} \mathrm{C}$ to $900{ }^{\circ} \mathrm{C}$. Likewise, in the Gd-modified composites, the primary $\mathrm{Mg}_{2} \mathrm{Si}$ particles refined considerably when the temperature increased from $750{ }^{\circ} \mathrm{C}$ to $850{ }^{\circ} \mathrm{C}$.

ii. Furthermore, with increasing the temperature to $900{ }^{\circ} \mathrm{C}$, the particle size increased slightly, which can be as a result of a loss of Gd in the melt due to burning. In higher superheat temperature, the heredity of the composite melt decreased, which led to the re-melting of all solid particles, impurities, and finer particles to be re-nucleated. These fine particles served as non-homogeneous nucleation substrate for precipitation of $\mathrm{Mg}_{2} \mathrm{Si}$ particles; therefore, little undercooling was required, and as a result, the fine $\mathrm{Mg}_{2} \mathrm{Si}$ particles were formed.

iii. The primary and eutectic $\mathrm{Mg}_{2} \mathrm{Si}$ morphologies were marginally affected by superheating temperature in unmodified and Gd-modified composites. However, refinement/modification of $\mathrm{Mg}_{2} \mathrm{Si}$ particles depicted the enhancement in hardness value of the composites.

\section{ACKNOWLEDGEMENT}

The authors wish to place their sincere thanks for financial and technical support by Department of Mechanical Engineering Faculty of Engineering under Research Grant of the Universitas Andalas (2019). The author also wish to acknowledge Department of Materials, Manufacturing and Industrial Engineering, School of Mechanical Engineering, Teknologi Malaysia as well as Department of Mechanical Engineering, Faculty of Engineering, Universitas Negeri Padang, and all the staffs involved for the valuable support provided during this research work.

\section{REFERENCES}

[1] Gu Z, Wang H, Zheng N, Zha M, Jiang L, Wang W, Jiang QC. Effect of melt superheating treatment on the cast microstructure of Mg-1.5 Si-1Zn alloy. Journal of Materials Science. 2008;43(3):980-984.

[2] Wang H, Jiang Q, Ma B, Wang Y, Wang J.G, Li J.B. Modification of $\mathrm{Mg}_{2} \mathrm{Si}$ in Mg-Si alloys with $\mathrm{K}_{2} \mathrm{TiF}_{6}, \mathrm{KBF}_{4}$ and $\mathrm{KBF}_{4}+$ $\mathrm{K}_{2} \mathrm{TiF}_{6}$. Journal of Alloys and Compounds. 2005;387(1-2):105-108.

[3] Ghandvar H, Idris MH, Ahmad N. Effect of hot extrusion on microstructural evolution and tensile properties of $\mathrm{Al}-15 \% \mathrm{Mg}_{2} \mathrm{Si}$ xGd in-situ composites. Journal of Alloys and Compounds. 2018;751:370-390.

[4] Czerwinski F. The generation of $\mathrm{Mg}-\mathrm{Al}-\mathrm{Zn}$ alloys by semisolid state mixing of particulate precursors. Acta Materialia. 2004;52(17):5057-5069.

[5] Aaron H, Idris M, Ang B, Nanda IP, Arafat A. Effect of casting and mould cooling temperatures on the warping phenomenon of aluminium at high pressure die-casting. Prosiding CELSciTech. 2018; 3:61-61.

[6] Haque M, Ismail AF. Effect of superheating temperatures on microstructure and properties of strontium modified aluminiumsilicon eutectic alloy. Journal of Materials Processing Technology. 2005;162:312-316. 
[7] Bian XF, Wang WM, Qin JY. Structures of liquid Al-Si alloy modified by Sr. Materials Science Forum 2000; 331-337: 349354.

[8] Zhong-wei C, Wan-qi J, Rui-jie Z. Superheat treatment of Al-7Si-0.55 Mg alloy melt. Materials Letters 2005;59(17):21832185 .

[9] Qiu D, Zhang M-X, Taylor J, Fu HM, Kelly PM. A novel approach to the mechanism for the grain refining effect of melt superheating of Mg-Al alloys. Acta Materialia 2007;55(6):1863-1871.

[10] Lee Y, Dahle A, StJohn D. The role of solute in grain refinement of magnesium. Metallurgical and Materials Transactions A 2000;31(11):2895-2906.

[11] Cao P, Qian M, StJohn DH. Mechanism for grain refinement of magnesium alloys by superheating. Scripta Materialia 2007;56(7):633-636.

[12] Qin Q, Zhao Y, Liang Y, Zhou W. Effects of melt superheating treatment on microstructure of $\mathrm{Mg}_{2} \mathrm{Si} / \mathrm{Al}-\mathrm{Si}-\mathrm{Cu}$ composite. Journal of Alloys and Compounds 2005;399(1-2):106-109.

[13] Li P, Nikitin V, Kandalova E, Nikitin KV. Effect of melt overheating, cooling and solidification rates on Al-16wt.\% Si alloy structure. Materials Science and Engineering: A 2002;332(1-2):371-374.

[14] Nordin NA, Abubakar T, Hamzah E, Farahany S, Ourdjini A. Effect of superheating melt treatment on Mg2Si particulate reinforced in Al- $\mathrm{Mg}_{2} \mathrm{Si}-\mathrm{Cu}$ in situ composite. Procedia Engineering 2017;184:595-603.

[15] Saffari S, Akhlaghi F. Influence of melt superheating on microstructure evolution in $\mathrm{Al}-\mathrm{Mg}_{2} \mathrm{Si}$ composites fabricated by gravity casting and vibrating cooling slope methods. In: Proceeding of Iran International Aluminum Conference (IIAC2014). Tehran, Iran; 2014.

[16] Yin F, Sun X, Li J, Guan HR, Hu ZQ. Effects of melt treatment on the cast structure of M963 superalloy. Scripta Materialia. 2003;48(4):425-429.

[17] Cao P, Qian M, StJohn DH. Effect of iron on grain refinement of high-purity Mg-Al alloys. Scripta Materialia. 2004;51(2):125129.

[18] Ghandvar H, Idris MH, Ahmad N, Emamy M. Effect of gadolinium addition on microstructural evolution and solidification characteristics of Al-15\% $\mathrm{Mg}_{2} \mathrm{Si}$ in-situ composite. Materials Characterisation. 2018;135:57-70.

[19] Shankar G, Kini A, Shettar M, Hiremath P. Aging kinetics and microstructural features of Al6061-SiC+ B4C stir cast hybrid composites. International Journal of Automotive and Mechanical Engineering. 2019;16(4):7211-7224.

[20] Latif NA, Sajuri Z, Syarif J. Effect of tensile strain rates on flow stress for extruded AZ31 and AZ61 magnesium alloys. International Journal of Automotive and Mechanical Engineering. 2017;14:3812-3823.

[21] Rajesh R, Sharma S, Gowrishankar M. Influence of solutionising and aging treatments on mechanical behavior of stir-cast eutectoid steel powder reinforced Al 7075 metal matrix composites. International Journal of Automotive and Mechanical Engineering. 2018;15(3):5583-5591. 